\title{
DIGITALCOMMONS
}

@WAYNESTATE-

Wayne State University

\section{Nothing but a Pack of Cards: Semi-fictitious Persons and Flopping Jellyfish in Elizabeth Bowen}

Renée C. Hoogland

Wayne State University, reneehoogland@wayne.edu

Follow this and additional works at: https://digitalcommons.wayne.edu/englishfrp

Part of the Aesthetics Commons, English Language and Literature Commons, Feminist, Gender, and Sexuality Studies Commons, and the Modern Literature Commons

\section{Recommended Citation}

Renée C. Hoogland (2011) 'Nothing but a Pack of Cards': Semi-fictitious Persons and Flopping Jellyfish in Elizabeth Bowen, Women: A Cultural Review, 22:1, 1-14, DOI: 10.1080/09574042.2010.488374

This Article is brought to you for free and open access by the English at DigitalCommons@WayneState. It has been accepted for inclusion in English Faculty Research Publications by an authorized administrator of DigitalCommons@WayneState. 


\section{'Nothing but a Pack of Cards': Semi-Fictitious Persons AND Flopping Jellyfish in}

\section{ELIZABETH BOWEN}

'If you don't know where you are going, any road will take you there.'

Lewis Carroll

'They were all "pictures." Images. "Nothing but a pack of cards"? — not quite, but nearly enough that to defeat Eva....Every soul Eva knew became no longer anything but a Portrait. There was no 'real life'; no life was more real than this. This she had long suspected. She now was certain.' Elizabeth Bowen, Eva Trout

Thus muses Eva Trout, the 'larger-than-life' protagonist of Elizabeth Bowen's final novel, ${ }^{1}$ when visiting the National Portrait Gallery in London at the near end of a story that ultimately cannot contain her, a story in which the eponymous heroine remains, in the words of Victoria Glendinning, both 'inexplicably large, and largely unexplained.' ${ }^{2}$ Such inexplicability has, of course, not prevented critics from trying to nonetheless "explain” Bowen's last, unnerving heroine, and the story she generates. None of these explanations_or interpretations-however, strike me as either particularly satisfying, or even adequate to the task imposed by this text. Indeed, what if the point of Eva Trout's existence - if there is a "point" to any literary character - in this narrative is precisely her inexplicability? What if Bowen's fantastic last heroine's elusiveness, as a sign, as a representation, is not so much a problem to be solved, but her very essence as a textual figuration? What if, to put it in slightly different terms, Eva's inscrutability is not a mystery to be explained, but something immanent, something essential to her "self," to the text in which she figures, and to the sociocultural context in which both she and her story originate? Taking Glendinning's suggestion in a different direction, then, we might stop to try and explain the inexplicable, and, instead, explore Eva Trout_or Changing Scenes, as the novel's subtitle reads - as an event, as, what Gilles Deleuze calls, the 'object of an encounter.' ${ }^{3}$ Such a Deleuzian optics, I suggest, as distinct from more traditional modes of interpretation, allows us, generally, to engage with Eva Trout - the novel—as an inscription and expression of a shifting sociocultural and conceptual landscape, and as a text that marks the change from a still largely modernist to a postmodernist cultural scene. More specifically, our encounter with the novel's unfathomable heroine can then be experienced as a confrontation with the ironies and $\mathrm{im} /$ possibilities of the search for meaning and significance in language and art, while the story in which she obtains actualizes a fabulation in which the search for meaning begins to take itself increasingly outside representation, gesturing towards a realm of expression that at once entails the evacuation of representation and that inevitably obtains within significatory forms. ${ }^{4}$ What I propose to do in this essay, then, is to approach Eva Trout not so much as a "person," a character, or a subject, and hence explicable as such, but instead, as what Deleuze calls a 'traitor-prophet,' a 'traitor to the world of dominant signification, and to the established order, ${ }^{5}$ be it of the novel, or the narrative in which she obtains, or in the larger domain of meaning-or, as the case may be, nonmeaning-production as such. 
Critics' difficulties with Bowen's last two novels are directly related to the fact that they differ, stylistically and structurally, quite substantially from her earlier work. The Little Girls (1964) ${ }^{6}$ and Eva Trout (1969) are usually placed in counter punctual juxtaposition with The Last September (1929) ${ }^{7}$ and Friends and Relations (1931), novels that have been both praised, and obliquely dismissed, as 'delicate small-scale post-Jamesian studies, mostly of children and adolescent girls, ${ }^{9}$ or characterized as 'deliberately' restricted ${ }^{10}$ — technically, as well as in terms of subject matter-'evocation[s] of class romance. ${ }^{11}$ Bowen's fiction of the late 1930s and 1940s has equally been qualified as modest drawing room dramas, a genre in which, according to some, the author found her ultimate strength, allowing her successfully to conjoin her 'historical attitudes, her literary manner, and her sense of a society. ${ }^{, 12}$ Her final two novels, in contrast, have led to widely diverging evaluations, even within the expanding body of Bowen criticism that has, in recent years, attempted to put an end to the author's longtime existence in a 'kind of critical limbo,' and to redress her status from a 'more or less middlebrow writer, ${ }^{13}$ to that of a 'significant figure within several key areas of contemporary study and interest. ${ }^{14}$

While generally well received upon its appearance in 1969, Eva Trout was dismissed by Hermione Lee, in 1981, as an 'unfocussed and bizarre conclusion to her opus,' whose main interest lies in the fact that it provides an 'illustration of Elizabeth Bowen's late malaise. ${ }^{15}$ Similarly perturbed by the novel's stylistic idiosyncrasies and its failure to conform to traditional notions of novelistic writing, Patricia Craig maintained in 1986 that, at the end of her writing career, Bowen 'has let her mannered manner run away with her,' while the novel's 'formidable' heroine in her view represents an 'impossibly inflated version of the Bowen destructive innocent. ${ }^{, 16}$ Marking the shift in more recent Bowen criticism, Andrew Bennett and Nicholas Royle, in what they claim to be the 'first theoretically informed reading of the complete novels' of Elizabeth Bowen, in contrast, not only set the author's novels apart as 'what happened after modernism,' but also assert that Eva Trout embodies 'nothing more and nothing less than the dissolution of the twentieth-century novel' per se. ${ }^{17}$ Responding to what she, somewhat unfairly, takes to be Bennett's \& Royle's challenge to read Bowen's work as a 'roller-coaster ride through groundless fantasies,' Maud Ellman's project, in Elizabeth Bowen: A Shadow Across the Page (2003), ${ }^{18}$ is to restore the 'ethical dimensions' of the author's work, identifying her final, 'colossal heroine' as the ground on which the 'disjunction' between ethics and the 'vagaries of modernist and postmodernist experimentalism'19 are battled out. ${ }^{20}$ Neil Corcoran, finally, in his 2004 study, Elizabeth Bowen: The Enforced Return, purports to direct his focus to the 'vibrating force' of Bowen's language, ${ }^{21}$ but appears eventually enforced to return to precisely the kind of psychobiographical criticism that has for so long left Bowen with the reputation of a minor writer of novels of sensibility - a genre of criticism that the author herself fiercely rejected. Construing the heroine of her final, 'ferociously rebarbative novel' as a 'kind of physical and psychological disfiguration ... a kind of incarnate damage, ${ }^{22}$ Corcoran reduces the stylistic distortions and linguistic disfigurations of the text to, 'on the part of the novelist herself,' the 'stress and pain' deriving from the 'connection, and the difference, between literary and maternal creativity. ${ }^{23}$ Posthumously attributing to Bowen a thwarted wish for procreation, Corcoran concludes that Eva Trout confirms the author's insight that fiction offers 'no consolation whatever' 
for the absence of a 'desired baby.' The broader lesson, he suggests, to be drawn from this— 'for the childed as well as the childless' - is that the 'categories of living and of making fictions are confused only at our greatest peril. ${ }^{24}$ With this rather grandiose, and, indeed, unwarranted statement, Corcoran does not only bring the traditional line of Bowen criticism full circle. His additional comment that this moral lesson gains particular significance because it 'should be written as Bowen's last word on the matter, ${ }^{25}$ is also simply wrong, in the sense of not true. For the actual last words on the 'relationship between living and writing,' appearing in print after the author's death, in 1973, comprise her unfinished autobiographical sketches, entitled, with reference to, not coincidentally, Lewis Carroll's Alice's Adventures in Wonderland, ${ }^{26}$ Pictures and Conversations (1974). ${ }^{27}$ Both texts appear to suggest that there is no clear difference between living and writing.

So, to take up Alice's question to the Cheshire cat: what road to take, where to begin to make sense, or no-sense, then, of this elusive narrative, and of its equally, if not more inexplicable heroine? The novel's plot, contrived, unrealistic, disjointed, and deliberately disorienting, is not going to be of much help. The text duly bears out its subtitle: its sixteen chapters, unequally divided into two parts, respectively entitled, 'Genesis,' and 'Eight Years Later,' comprise a haphazard series of 'changing scenes.' Indeed, with Eva Trout, the author takes her predilection for the typical Bowen character, 'outlandish,' 'displaced persons,' who are not only 'in transit,' but 'in transit consciously'- to its extreme. Eva is constantly, quite literally in motion; she is continually leaving, escaping, fleeing. But, though troublesome to her fellow characters, such fleeing is not merely to be read as an attempt to get away from things. In Deleuzian terms: 'To flee is not to renounce action: nothing is more active than a flight...to fly is to trace a line, lines, a whole cartography. ${ }^{28}$ Tracing the lines of its protagonist's myriad flights, the text of Eva Trout becomes a cartography: putting something to flight, bursting the tube of representation, of realism, a flighty, ruptured narrative, nomadic, nonfixed, adventures/adventurous beyond the foreseeable. As a result, neither paraphrase nor genre definitions can do justice to the text's meanderings, nor, indeed, to its humor and indomitable energy - a dual risk I nonetheless have no choice but to take.

Variously defined as a black comedy, a novel of development, a picaresque, a farce, and a folly, Eva Trout revolves around its 'monstrous' heroine, whose erratic life history gradually emerges from fragmentary information provided by other characters, and through the letters, confessions, and diary entries that intersperse the comments and observations of the equivocal narrative voice. Eva is throughout presented from the outside: if she has any thoughts—and one of the novel's achievements is to make us question this possibility-neither her readers nor her observers are allowed to share them. Conventional inside/outside distinctions do not obtain: Eva Trout is not a character with a recognizable 'interiority,' but rather exists, comes into empirical existence, in and through her encounters with others, i.e., in the otherness of language, as much as in the responses, discursive and otherwise, of characters whose thoughts we do share, to whom we are invited to attribute the ontological illusion of an internal life, and that she, as radically other, cannot but affect profoundly. As one of the characters aptly remarks, Eva 'leaves few lives unchanged. Or at least, unscathed' (ET 196). 
Defying the conventional distinction between inside and outside, between subject and object, between mind and body, Eva is a 'traitor' to the world of dominant signification in another respect as well, in that she has escaped, and, as we will see, will continue to do so, the normativizing process of Oedipal triangulation. In a flashback, we learn that the girl, 'motherless from the cradle' (ET 35), has spent her early years accompanying her father Willy Trout, a 'business man fortunate in his back ground,' and a 'crack polo player' (ET 11), on his global business trips, living under the shadow of Willy Trout's 'total attachment' to his male lover, Constantine Ormeau (ET 10). A stint at a progressive experimental school, set up by her father in order to keep Constantine's new friend, 'inspirational Kenneth of the untouched brow and Parthenon torso' (ET 44/5), at bay, when Eva is thirteen, had briefly interrupted these travels. When scandals forced the educational establishment to close down, Eva resumed her peripatetic existence. Two further years of travel eventually had landed her, almost sixteen, at an English boarding school for girls, where she meets and enters into a 'pact,' about which 'to anyone looking back' there 'could have seemed to be something occult' — and the narrator parenthetically reassures us that '(Eva never did)' (ET 60)_-with a brilliant young teacher, Miss Smith.

The novel opens eight years later, in the Worcestershire countryside, where Eva, in anticipation of her financial independence - she is to come into her inheritance on her next, twenty-fifth birthdayis staying as a paying guest at Larkins, the home annex (failed) fruit farm inhabited by her former teacher, Iseult Arble_-formerly Smith_and her husband Eric. Her father, having it in him to deviate,' has committed suicide a few years previously. While at Larkins, Eva befriends the Dancey family, i.e., the country vicar, his wife, and their four children, among whom perversely charming twelve-year-old Henry. Iseult Arble, introduced as a 'highly intelligent person, young still, of pleasing appearance and good character' (ET 10) had seemed 'destined to have Eva' (ET 7), when she was left as a 'legacy, on the hands of Constantine' (ET 11). But things do not turn out well: for reasons that do not become immediately clear, Eva flees from the home of her once 'brilliant teacher,' to take up residence in Broadstairs, Kent, in a house named Cathay, where she is subjected to a number of unsolicited visits from her various unwanted guardians, before taking off again, this time for the United States. The next time we meet her, the giant heiress is in Chicago, on her way to buy a child on the black adoption market. Yet another eight years later, she returns to England in the company of her deaf-mute son, Jeremy. Apparently longing to reconnect with her former acquaintances, Eva is also afraid that something might happen to her son, and, continuing to draw out her lines of flight, she spends her time traveling from London hotels to Paris and Fontainebleau, eventually to return to England, where she sets in motion a final tour de force, her make-belief marriage to the now twenty-year-old Cambridge student Henry Dancey. This grand finale at Victoria Station ends with the heroine's death at the hands of her son, who has, through some incongruous and complicated plotting, been able to get hold of a gun left by Iseult among Eva's hotel-stored possessions.

The explosive restlessness of the novel's plot—as Ellman rightly maintains, 'chance, rather than choice, determines the sequence of events ${ }^{29}$ — is reflected in the equally whimsical operation of its 
textual strategies, and, indeed, in the capricious materialization of its inscrutable protagonist. Instead of seeing such chanciness as an attempt to 'devis[e] a new kind of novel for an age in which ... the world can be destroyed by accident,' as Ellman does ${ }^{30}$ —or, indeed, as a 'dissolution of the twentiethcentury novel,' as Bennett \& Royle do-I propose that Eva Trout expresses, narratively, discursively, and affectively, what Deleuze calls 'becomings,' a process whose forever provisional 'outcomes' cannot be captured in the chains of signification, but can only be suggested in/through style:

Becomings - they are the thing which is the most imperceptible, they are acts which can only be contained in a life and expressed in a style. Styles are not constructions, any more than are modes of life. In style it is not the words which count, nor the sentences, nor the rhythms and figures. In life it is not the stories, nor the principles, nor the consequences. (Dialogues, 3)

Suggested — and thus undercut—by being precariously captured in the style of Bowen's writing, it is, transversally, Eva's 'charm,' in a Deleuzian sense, as not so much a person, but rather as that which 'makes people be grasped as so many combinations and so many unique chances from which such a combination has been drawn,' ${ }^{31}$ that not only makes her 'larger-than-life,' as a character in relation to the other characters in the novel, as much as to her readers, but that also throws the worlds in which she keeps drawing her irreducible maps, living and moving by chance, by what seems to be no more than a throw of the dice, into profound confusion. It is furthermore the 'vibrating force' of Bowen's language, the intensity of her putatively overly 'mannered manner,' indeed, her excessively idiosyncratic style that makes it clear that it is precisely in the chanciness of writing, in the stuttering and stammering of representation-visual and linguistic - that the possibility of some mode of affirmative, creative being, in the Deleuzian sense of becoming, resides.

The complexity and irreducibility of subjectivity, or, more generally, the instability of meaning, is, of course, immediately suggested by the heroine's name, at once inscribing the larger text of the Christian myth of creation-or, as the title of the novel's first part indicates, Western culture's coming into being, or genesis - and the slippery nature of personhood. Eva's tendency to make up fictions, her inclination to fabulation, i.e., her ability to go beyond consensual reality, is reflected in Bowen's use of past myths, not quite in mockery or parody, but more in the nature of a reconfiguration, and reinforces her final heroine's refusal to be contained in already determined and constituted stories. The mythopoetic function of art and literature finds expression in Eva's disconcerting creative powers-disconcerting, that is, to others, not to herself, a fact she appears to be fully aware of, when asked what she thinks others think of her: "'Oh, yes. They agree, I am a liar," said Eva - though easily, and looking about her at the lovely transparency of the rising shadows without rancour or air of trouble' (ET 248). It is her ability to invent (different life courses for) herself, to trace her own li(n)es of flight that allows her to see that there is 'no "real life",' that 'no life was more real than this,' in the passage quoted earlier, which closely follows upon a phone call she has received from her former teacher Iseult Smith, after her return from the US. 
Not having seen or spoken to Miss Smith for eight years, Eva, after the incident, finds herself wondering: 'Had this been Miss Smith, or was she dead and somebody impersonating her?' (ET 212). Not quite convinced by X's impersonation of Miss Smith—the 'voice's inflexions, even, had been, if not quite parodied, exaggerated, over-stretched, harshened' (ET 212), Eva, struck by the 'impression of dissolution' the person at the other end of the line had given, considers another possibility: 'The impersonator had been Miss Smith, a deceased person purporting to be a living one'-a conclusion that calls to mind another of Lewis Carroll's memorable phrases: 'It is no use going back to yesterday, because I was a different person then. ${ }^{32}$ The volatility of personhood, the chanciness of being, disclosed as a process of endless becoming, thus being established, the narrative voice steps in to observe: 'Anyhow, what a slippery fish is identity; and what is it besides a slippery fish? ... What is a person? Is it true there is not more than one of each?' (ET 213). Neither Eva, nor the reader, it will be clear, is offered a clear-cut answer to these questions. Underscored by Lewis Caroll's implicit presence in this passage — and it is surely no coincidence to find both Bowen and Deleuze reference Carroll in their respective explorations of the 'chaos-cosmos,' the 'play of sense and nonsense, ${ }^{33}$ that is central to all three writers' work-the sequence of questions rather suggests that neither pictures nor conversations, to recall the title of Bowen's autobiographical sketches, or any other system of signification can capture or guarantee meaning, or even stability, whether of character, identity, or personhood. Eva, the 'giantess' (ET 5), with her 'outlandish, cement-like conversational style' (ET 10), forms both the embodiment and the inscription of such slipperiness. Indeed, as one of the novel's characters observes, 'Trout's not a usual name except for a fish' (ET 148). As a 'traitorprophet' in the sociosymbolic order, and in the text in which she obtains as a character-event, Eva instantiates the paradox of the 'play of sense and nonsense' that Deleuze designates 'pure becoming' in language, which 'fixes the limits...but which [also] transcends the limits and restores them to the infinite equivalence of an unlimited becoming. ${ }^{34}$

Maud Ellman posits that Eva Trout 'sets up a contest between "pictures and conversations", an opposition between words and images, in order to suggest that the former can 'achieve' what the latter cannot: 'Interiority. ${ }^{, 35}$ Setting up a further contrast between Iseult Smith-the 'wonderful teacher' (ET 56), whose medium is language, and Eva, on whom it is brought to bear that, at age sixteen, she is 'unable to speak — talk, be understood, converse' (ET 62)_Ellman argues that Eva is 'desperate to become a character... searching for an author to provide her with an inner life. ${ }^{36}$ In her otherwise careful and perceptive reading of this conflict between images and words, especially of the way it works out after Eva and Jeremy leave their shared existence in a 'visual universe,' a 'cinematographic existence, with no soundtrack' during the 'at-large American years' (ET 208), Ellman makes the mistake of sustaining this conflict in terms of a binary opposition that ultimately requires the novel to choose in favor of either one or the other, i.e. for pictures or conversations. This, she admits, the novel does not actually do: Bowen leaves the answer to these questions dangling, 'turn[ing] off the voice-over, depriving the reader of the guidance of the narrator. ${ }^{37}$ Ellman's desire for (the possibility of) interior being, however, her longing for a 'penetration of the depths,' instead of the 'snapshot of the surface, ${ }^{38}$ urges her to impose a reading on the novel, and on the complex questions of ethics and being in the world it evokes, that runs counter to everything 
Eva Trout/Eva Trout_ — as a text and as a character_effect. Thus, she eventually concludes that Eva's betrayal of Jeremy, her willingness, after her return to England, to enter the domain of speech, leaving her son behind in the silence of a world they once used to share, a 'story to which they imparted the only sense' (ET 208), not only explains Jeremy's desire to kill his adoptive mother'brought to life by love and language' — but also leads to the inevitable inference that 'Eva has_-or had-an inside after all.' 'When Jeremy shoots Eva,' Ellman contests, he 'also shatters the delusion that a person is nothing but a picture. ${ }^{39} \mathrm{I}$ would argue, on the contrary, that there is nothing in terms of reassurance - the reassurance of finite being, the reassurance of unruptured signification, of firm distinctions between inside/outside, words/images, to be found in this novel. Rather, as a text whose effects are determined by its volatile, excessive style rather than by the meaning of its constituting words and sentences, and as an 'inexplicable' character who operates through her tantalizing, yet compelling charm, rather than the principles of subjectivity, Eva Trout/Eva Trout provoke their readers into becoming otherwise. There is no identity here, no possibility of identification, there is merely the work of art as a field of possible becomings, of virtualities that one can decide either to accept or to refuse. Or, to cite Deleuze's co-author and counterpart, Félix Guattari:

Art confers a function of sense and alterity to a subset of the perceived world...the work of art, for those who use it, is an activity of unframing, of rupturing sense, of baroque proliferation or extreme impoverishment, which leads to a recreation and a reinvention of the subject itself. (Chaosmosis 131)

Not unlike Corcoran, then, whose projection of a 'desired child' onto the author issues in his earlier cited conclusion that the moral of the story is that the 'categories of living and of making fictions are confused only at our greatest peril, ${ }^{, 40}$ Ellman, in her insistence on restoring the 'ethical dimensions' of Bowen's work, does not 'use' Eva Trout as an 'activity of unframing,' and ends up by superimposing a narrowly defined, liberal humanist paradigm on the novel, which her own careful reading of its complexities actually defies. For neither the assumed opposition between words and images, nor its suggested resolution in favor of an inner life produced in/by language, do justice to the contradictions that are held in suspense, the 'play of sense and nonsense,' on both the discursive and the narrative level of the text, that constitutes the possibility for a productive encounter, an event, which, to cite Guattari again, 'generate[s] fields of the possible "far from the equilibria" of everyday life. ${ }^{41}$ Perhaps even more pronouncedly than in its eponymous heroine, the implications of the novel's 'rupturing' force are expressed through the character that is most queerly interconnected to Eva, the intellectually accomplished and desperate defender of systemic language, yet ultimate victim of its failures, Iseult Smith.

Iseult Smith, set up as the representative of prevailing systems of reference, of the Oedipal and the sociosymbolic order, is not only a brilliant teacher, but also, significantly, a failed novelist. The interiority, and the fulfillment of subjective being that language, according to Ellman, may achieve, and especially over and above the power of images, is seriously called into question by the fact that 
Miss Smith is initially reported to have abandoned a 'star career for an obscure marriage,' founded on a 'cerebral young woman's first physical passion' (ET 10). Whereas it may seem that the text here invokes the traditional opposition between body and mind, emotions and intellect, and comes out in favor of the latter, Miss Smith's history undercuts such assumptions. For, we learn, even after she has left her husband to go off to France to write a novel, the power of words fails her, because, as Simon O'Sullivan aptly points out, the 'making of connections, the production of encounters,' in and through art, must be 'paralleled by a vigilance of the body-mind. ${ }^{42}$ Having undergone what she describes as an 'emotional hysterotomy' (ET 251), the novel Miss Smith was supposed to write turns out to have been 'born dead' (ET 253), leading to the conclusion that her 'inside's gone' (ET 250). Despite her 'illumined intelligence' (ET 60), her great gift for teaching, and her years of 'uninhibited letterwriting' (ET 228), words have obviously not succeeded in providing the 'bookish,' once marvelous teacher with the possibility of creative becoming, of making connections-let alone with an abiding sense of self, with interiority. Indeed, as she submits in a diary entry appearing verbatim in an early chapter of the novel_- 'flex[ing] her fingers over the keyboard,' and 'angl[ing] the lamp over the typewriter, to see more clearly what it was about to tell her' (ET 94)- -her search for a self in words, in writing, has so far not been particularly successful. We are once again reminded of Alice in Wonderland's self questioning: 'Who in the world am I? Ah, that's the great puzzle, ${ }^{43}$ when Iseult is forced to concede: 'How inconceivable oneself is' (ET 95). The main question, however, remains whether having an inner live, interiority, as a result of words and thought, is such a good thing to begin with. For Miss Smith it evidently is not, for she continues her nocturnal musings by admitting that she is 'capable de tout,' being 'soiled by living more than a thousand lives,' having lived 'through books,' having lived, indeed, 'internally' (ET 96). This failure at 'finding herself in/through words, in/through language, however, has profound impact on her relationship with Eva, as much as it is Eva, not being in/on the same plane of this vicarious existence, who throws Iseult's sense of (her)self, her im/possible hope of be(com)ing someone through writing, into disarray. This much seems clear from Miss Smith's disruptive encounter with Eva, when the latter first enters her classroom.

Iseult Smith's initial, 'vivisectional interest' (ET 27) in her ostensible counterpart is aroused by Eva's apparent inability to think, or rather, to connect the thoughts that, like time, 'lay about [in her mind] like various pieces of a fragmented picture' (ET 42). Eva, who is perceived at school as 'partly foreign, partly handicapped,' though 'in what particular or for what reason she was taken to be the latter was not gone into' (ET 60), is altogether illegible within the terms of consensual reality. So much so that one of her fellow pupils at some point feels forced-and Bowen would not be Bowen if she would not keenly suspect the gendered nature of both language and being - to ask her: "'Trout, are you a hermaphrodite?" (ET 48). Miss Smith takes it upon her to transform Eva into a legible text, to provide her with what Ellman would call, an inner life: “'Try joining things together: this, then that, then the other. That's thinking; at least, that's beginning to think"' (ET 61). But Eva turns out to be a resisting reader, not quite seeing the point of it, and is furthermore afraid that, 'at the end of it all,' she'll have 'nothing to declare' (64). Miss Smith, suspecting that the 'monstrous heiress' 'would rather go on being submerged' (ET 64), acknowledges the hopelessness of the 
undertaking, and eventually leaves her charge 'unfinished' (ET 60). But who is losing out on whom here? Is it Eva, who fails adequately to respond to the call of symbolization and subjectivity, or is it Iseult, who refuses to make the real break of habit (of thought, of being) that her encounter with this uncouth pupil threatens to provoke?

It later transpires - in one of the confessions that, like so many other forms of direct discourse that are strewn about the narrative passages - that it is the unfinished business of the attempted initiation into language that causes the 'pact' between Iseult and Eva to break up. Being paid a morning visit by a new friend of Constantine's_ _ 'young East-End priest. Anglican naturally' (ET 190), Eva is urged to confess: 'She desisted from teaching me. She abandoned my mind' ... '[she] sent me back again — to be nothing' ... 'I remain gone. Where am I? I do not know-I was cast out from where I believed I was' (ET 203). This is only, however, after another pact, i.e., that between Eva and Jeremy, and their shared lives within a wordless, visual universe has ended, soon after their return to England. Plunged into what was a 'void for him,' but what is 'at the same time dense with experiences' (ET 209) for her, Eva, suddenly finds herself 'ready to talk' (ET 207). Just as the pictures at the National Portrait Gallery, however, 'present[ing] a cool core of resistance even to the most penetrating artist,' remaining their 'own affair,' so that 'nothing [is] to be learned from them,' the stories or words in which such pictures/images obtain have very little to offer to Eva, do not really 'arrive[ at something' (ET 61): 'One plot unraveled, another knitting. Re-alignments, out-ofcharacter overtures, fresh fancies budding from hoary boughs' (ET 216). Neither images nor words, it seems, are capable of enchaining Eva, of containing her infinite, roaming actuality and transforming it into something more ostensibly 'solid,' into a subject, or even a character with an 'inner life.' For, in the end, even this text full of pictures and conversations, in which the tension between words and images is not, as I have suggested, resolved, but ultimately held in abeyance, cannot contain its own heroine, 'outsize, larger-than-life in every way' (ET 262). The novel's final image is captured in the words 'dead body' -Eva's, that is (ET 302).

Rather than suggesting the redeeming powers of language, or words, as Ellman would have it_Eva, after all, dies only after she has become ready and willing to speak—or, alternatively, a sense of despair about a future without language, as Lee suggests — a conclusion gainsaid by the sardonic joy with which the author of this 'roller-coaster' tale obviously revels in her own stylistic excessesBowen's final novel masterfully points up the uncontainability of being in representation, and, paradoxically, the simultaneous inevitability, indeed, the ethical imperative to use the poetic function of language, i.e., over and beyond its representational operations, to draw lines of flight into possible worlds, to make a break in/through the imagination, in order to forge new assemblages, new existential refrains, new modalities of being.

Eva's unfeasibility qua representation, in the sense of re-presentation, i.e., the fact that, as Iseult Smith at some point avers, a 'second Eva would have been not only unthinkable but impossible' (ET 271), hence does not spring from her 'passion for the fictitious for its own sake' (ET 270), nor from living her life as what, according to Constantine, is a 'harlequinade' (ET 188). Instead, Eva's 
outlandishness derives from her simultaneous desire and her inability, or unwillingness, to enchain her self in representation-visually, or linguistically. Eva, as Henry points out, 'plunge[s] people's ideas into deep confusion' (ET 197), not because she confuses the 'categories of living and of making fictions,' to recall Corcoran's verdict, but because she does not: she essentially obviates any such clear-cut distinctions. It is Henry, in the end, the one 'person' who genuinely comes to love Eva, and who, because of his readiness to take her on as a virtual reality, as that which is not yet, may never be, most clearly realizes that a 'role,' therefore, needs to be 'project[ed]' for her (ET 196). The 'awful thing,' he surmises, about Eva is not that she makes up things, up to and including the make-believe wedding scene at the end of the novel. In fact, as Henry reflects, an 'unreal act collects round it real-er emotion than a real act, sometimes' (ET 293). The reason why Eva 'ethically perhaps [is] a typhoid Mary,' as he articulately puts it, is that she is 'artless,' and therefore 'roll[s] around like some blind indeflectable planet' (ET 197).

Neither the distinction between words and images-Bowen was, after all, in her own words, very much a 'visual writer" combustion' in this restless tale of restless be(com)ing-or non-be(com)ing. In what are truly her last words on these subjects, the earlier mentioned autobiographical sketches, the author makes abundantly clear that, in her mind, being without art, or being artless, eventually results in non-being, however elusive such mode of virtual be(com)ing may inevitably turn out to be. Rather than drawing her characters from real life, she points out, that, for the first twenty years of her life, 'if anything, the contrary was the case: persons playing a part in my life ... had about them something semifictitious. Born with no idea what people were like, I made guesses at them.' That these persons made 'no objection' to such guesses is not so surprising, she continues, for 'it is something to have "character" attributed to one, of whatever kind.' Since it is from the subsequent, explanatory sentences that I have borrowed part of my title, they deserve to be quoted in full:

For a main trait of human nature is its amorphousness, the amorphousness of the drifting and flopping jellyfish in a cloudy tide, and secret fears (such as the fear of nonentity) ... prey upon individuals made aware of this. There results an obsessive wish to acquire outline, to be unmistakably demarcated, to take shape ... Fictional characters stand out, enlarged by doing so. That their power is given them by art does not (indeed, must not) appear. They are; thereby their effect is tonic. ${ }^{45}$

The case of Eva Trout, I propose, not only confirms that the absence of art, or artlessness, leads to the impossibility of being-or, rather, becoming-but also that, in order to become, or even to begin the process of be(com)ing, one needs pictures and conversations that break through representation and symbolization. Indeed, to return once more to Guattari, in order to escape from 'dominant subjective formations,' and to open up the realm of possibilities, what is required is the 'fractalization, processualization and existential recomposition' offered by art-for those who want to use it that way - to be willing to encounter the work of 'art as a break, but also as the germ for a new synthesis. ${ }^{46}$ Acting as an expression of such an agent provocateur, the traitor-prophet character of 
Eva Trout, as much as the 'rebarbative' text of Eva Trout, actualize such disconcerting 'forces' of deand re-composition - staging an event of deterritorialization, and, withholding the reassuring option of interpretation, put the reader's sense of herself at risk for the sake of intensification and sensation - a fact that may go some way to explain the critical dissent, if not the outraged dismissal of Bowen's unsettling final novel.

This would have been the end of this essay, my attempt to trace some lines in and out of a text that has proven so difficult to read, that resists being captured in the traditional terms of conventional criticism, of liberal humanism, of modernism, if it were not for the haunting presence of another plane of expression, of $\mathrm{im} /$ possible becoming, i.e., the work of an author who has hovered so insistently between the lines of my argument, as he, indeed, does over the changing scenes of Bowen's capricious heroine's chancy, and, ultimately, uncontainable existence.

I end, therefore, the way I began, by citing the words of Lewis Carroll:

And the moral of that is: 'Be what you would seem to be'-or, if you'd like it put more simply-'never imagine yourself not to be otherwise than what it might appear to others that what you were or might have been was not otherwise than what you had been would have appeared to them to be otherwise. ${ }^{47}$ 
Notes

${ }^{1}$ Elizabeth Bowen, Eva Trout, or Changing Scenes (New York: Anchor Books, 2003). Hereafter referred to as ET followed by page numbers.

${ }^{2}$ Victoria Glendinning, Elizabeth Bowen: Portrait of a Writer (Harmondsworth, Middlesex: Penguin Books Ltd., 1977). p. 225.

${ }^{3}$ Gilles Deleuze, Difference and Repetition, Trans. Paul Patton (New York: Columbia University Press, 1994) 139.

${ }^{4}$ The term fabulation, popularized by Robert Scholes in his book The Fabulators (1967) refers to a mode of modern fiction that openly delights in its self-conscious verbal artifice, thus departing from the conventions of realism.

${ }^{5}$ Gilles Deleuze \& Claire Parnet, Dialogues, trans. H. Tomlinson and B. Habberjam (London: Athlone Press, 1987) 41.

${ }^{6}$ Elizabeth Bowen, The Little Girls (Harmondsworth: Penguin, 1982).

${ }^{7}$ Elizabeth Bowen, The Last September (London: Vintage, 1998).

${ }^{8}$ Elizabeth Bowen, Friends and Relations (Harmondsworth: Penguin, 1982), Bowen, Last September, Bowen, Little Girls.

${ }^{9}$ Douglas Hewitt, English Fiction of the Early Modern Period, 1890-1940 (London \& New York: Longmans, 1988).pp. 196-7.

${ }^{10}$ Ibid. p. 198.

${ }^{11}$ Rosalind Miles, The Female Form: Women Writers and the Conquest of the Novel (London: Routledge, 1990)., p. 30.

${ }^{12}$ Hermione Lee, Elizabeth Bowen: An Estimation, Critical Case Studies (London \& Totowa, NJ: Vision \& Barnes and Noble Books, 1981).p. 191.

${ }^{13}$ Neil Corcoran, Elizabeth Bowen: The Enforced Return (Oxford: Clarendon Press, 2004). 11.

${ }^{14}$ Andrew Bennett \& Nicholas Royle, Elizabeth Bowen and the Dissolution of the Novel (Basingstoke: Palgrave, 1995).p. xiii.

${ }^{15}$ Lee, p. 206.

${ }^{16}$ Patricia Craig, Elizabeth Bowen (Harmondsworth, Middlesex: Penguin Books Ltd, 1986). 135.

${ }^{17}$ Bennett \& Royle, p. xv.

${ }^{18}$ Maud Ellman, Elizabeth Bowen: The Shadow across the Page (Edinburgh: Edinburgh University Press, 2003).

${ }^{19}$ Bennett \& Royle, p. xiv.

${ }^{20}$ Ellman, p. 204.

${ }^{21}$ Corcoran, p. 4.

${ }^{22}$ Ibid. p. 8; p. 131.

${ }^{23}$ Ibid. p. 141.

${ }^{24}$ Ibid. p. 144.

${ }^{25}$ Ibid.

${ }^{26}$ Lewis Carroll, Alice's Adventures in Wonderland (London: Penguin Books Ltd., 1998).

${ }^{27}$ Elizabeth Bowen, Pictures and Conversations: Chapters of an Autobiography with Other Collected Writings (London: Allen Lane/Penguin Books Ltd., 1975). 61.

${ }^{28}$ Deleuze, Dialogues, p. 36.

${ }^{29}$ Ellman, p. 212.

${ }^{30}$ Ibid.

${ }^{31}$ Deleuze, Dialogues, p. 5. 
${ }^{32}$ Carroll, p. 133.

${ }^{33}$ Gilles Deleuze, The Logic of Sense, Trans. Mark Lester, with Charles Stivale (New York: Columbia University Press, 1990) xiii.

${ }^{34}$ Ibid. pp. $2 / 3$.

${ }^{35}$ Ellman, p. 206.

${ }^{36}$ Ibid. p. 216.

${ }^{37}$ Ibid. p. 221.

${ }^{38}$ Ibid. p. 223.

${ }^{39}$ Ibid.

${ }^{40}$ Corcoran, p. 144.

${ }^{41}$ Guattari, p. 131.

${ }^{42}$ Simon O'Sullivan, Art Encounters Deleuze and Guattari: Thought Beyond Representation (Basingstoke \& New York: Palgrave MacMillan, 2007) p. 92.

${ }^{43}$ Carroll, p.16.

${ }^{44}$ Pictures and Conversation, p. 60.

${ }^{45}$ Ibid., pp. 58/9.

${ }^{46}$ O’Sullivan, p. 92.

${ }^{47}$ Carroll, Alice's Adventures in Wonderland. p. 114.

Works Cited

Bowen, Elizabeth. Eva Trout, or Changing Scenes. New York: Anchor Books, 2003.

- Friends and Relations. Harmondsworth: Penguin, 1982.

- The Last September. London: Vintage, 1998.

- The Little Girls. Harmondsworth: Penguin, 1982.

- Pictures and Conversations: Chapters of an Autobiography with Other Collected Writings. London: Allen Lane/Penguin Books Ltd., 1975.

Carroll, Lewis. Alice's Adventures in Wonderland. New York: Weathervane Books, 1978.

Corcoran, Neil. Elizabeth Bowen: The Enforced Return. Oxford: Clarendon Press, 2004.

Craig, Patricia. Elizabeth Bowen. Harmondsworth, Middlesex: Penguin Books Ltd, 1986.

Deleuze, Gilles \& Claire Parnet, Dialogues, trans. H. Tomlinson and B. Habberjam. London: Athlone Press, 1987.

Deleuze, Gilles. The Logic of Sense. Trans. Mark Lester, with Charles Stivale. New York: Columbia University Press, 1990.

Deleuze, Gilles. Difference and Repetition. Trans. Paul Patton. New York: Columbia University Press, 1994.

Ellman, Maud. Elizabeth Bowen: The Shadow across the Page. Edinburgh: Edinburgh University Press, 2003.

Glendinning, Victoria. Elizabeth Bowen: Portrait of a Writer. Harmondsworth, Middlesex: Penguin Books Ltd., 1977.

Guattari, Félix. Chaosmosis: An Ethico-Aesthetic Paradigm. Trans. Paul Bains and Julian Pefanis. Sydney: Power Publications, 1995.

Hewitt, Douglas. English Fiction of the Early Modern Period, 1890-1940. London \& New York: Longmans, 1988.

Lee, Hermione. Elizabeth Bowen: An Estimation, Critical Case Studies. London \& Totowa, NJ: Vision \& Barnes and Noble Books, 1981. 
Miles, Rosalind. The Female Form: Women Writers and the Conquest of the Novel. London: Routledge, 1990.

O’Sullivan, Simon. Art Encounters Deleure and Guattari: Thought Beyond Representation. Basingstoke \& New York: Palgrave MacMillan, 2007.

Royle, Andrew Bennett \& Nicholas. Elizabeth Bowen and the Dissolution of the Novel. Basingstoke: Palgrave, 1995. 